\title{
Modeling the influence of Climate Change on Watershed Systems: Adaptation through Targeted Practices
}

\author{
By
}

John Dudula ${ }^{1}$ and Timothy Randhir ${ }^{2 *}$

1. Graduate Research Assistant, Department of Environmental Conservation, University of Massachusetts, Holdsworth Natural Resources Center, Rm. 312b, Amherst, MA 01003.

2. (*Corresponding author) Professor, Department of Environmental Conservation, University of Massachusetts, Holdsworth Natural Resources Center, Rm. 326, Amherst, MA 01003, Phone: (413) 545-3696, E-Mail: Randhir@eco.umass.edu /_trandhir@gmail.com

Acknowledgements: This material is based upon work supported by the Cooperative State Research Extension, Education Service, U.S. Department of Agriculture, Massachusetts Agricultural Experiment Station, under Projects, 0233326, MA500864, MAS000943, NE-1024, and NE-1044. All data for this paper is properly cited and referred in the reference list. Please contact Timothy Randhir at Randhir@eco.umass.edu for additional data access information. 


\begin{abstract}
Climate change may influence hydrologic processes of watersheds (IPCC, 2013) and increased runoff may cause flooding, eroded stream banks, widening of stream channels, increased pollutant loading, and consequently impairment of aquatic life. The goal of this study is to quantify the potential impacts of climate change on watershed hydrologic processes and to evaluate scale and effectiveness of management practices for adaptation. We simulate baseline watershed conditions using the HSPF (Hydrological Simulation Program Fortran) simulation model to examine the possible effects of changing climate on watershed processes. We also simulate the effects of adaptation and mitigation through specific best management strategies for various climatic scenarios. With continuing low-flow conditions and vulnerability to climate change, the Ipswich watershed is the focus of this study. We quantify fluxes in runoff, Evapotranspiration, infiltration, sediment load, nutrient concentrations under baseline and climate change scenarios (near and far future). We model adaptation options for mitigating climate effects on watershed processes using bioretention/ raingarden Best Management Practices (BMPs). It was observed that climate change has a significant impact on watershed runoff and carefully designed and maintained BMP's at subwatershed scale can be effective in mitigating some of the problems related to storm water runoff. Policy options include implementation of BMPs through education and incentives for scale-dependent and site specific bioretention units/ raingardens to increase the resilience of the watershed system to current and future climate change.
\end{abstract}

Keywords: watershed modeling, climate change, BMP, adaptation, storm water. 


\section{Introduction}

Climate change, through changes in timing and patterns of precipitation and temperature, is likely to impact water resources (IPCC, 2013). The global land and ocean surface temperature, show a warming of $0.85^{\circ} \mathrm{C}$ during 1880 to 2012 (IPCC, 2013), with recent decades warmer than prior decades. The Fifth Assessment Report (AR5) of IPCC observes that one of the most serious impacts of climate change is expected changes in surface runoff, especially in areas with impervious surfaces such as roads, parking lots and buildings (IPCC, 2013). Climate change impacts on runoff could be significant (Ekness and Randhir, 2016; Arnell and Gosling, 2013; Doll and Schmied, 2012). Some of the long-term effects of these changes on watershed ecosystems are increased stress to stormwater drainage systems and reduced habitat quality of aquatic ecosystems (Zoppou, 2001). There is a need for assessing impacts of climate change under varying future time scales and potential for adaptation through BMPs at a watershed scale.

Climate change impacts on watershed ecosystems and hydrological processes are complex. Warming may cause shifts in the timing of streamflow in North America (Frize et al, 2011) with implications in areas where water supplies are limited or overcommitted. Warmer temperatures in January and March may influence changes in the timing of runoff peaks. Changing climate can affect runoff patterns and timing in urban watersheds that have higher peak discharge and lower time-of-concentration in stormwater flows. This could have significant impact on stream ecosystems. In regions with higher expected precipitation, urban drainage systems receive volumes of water that could exceed their capacity to collect and redirect water to storage channels. Increases in precipitation intensity and duration can lead to increased flooding, eroded stream banks, widening of stream channels, polluted waters, impairment to aquatic ecosystems, changes in recreation use, threats to public health and safety, and economic impacts as well as increased 
costs of water and wastewater treatment. Land use changes through changes in impervious cover and alteration of watercourses (Zoppou et al. 2000) can further exacerbate climate induced problems in many watersheds (Marshall and Randhir, 2008).

Adapting to climate change is becoming a major part of the strategy to manage stormwater runoff in urban watersheds. Understanding the effectiveness of adaptation strategies and best management practices (BMPs) in order to mitigate hydrologic changes is critical for effective water resource management (Geosyntec Consultants, 2014).

Urban stormwater runoff is a significant source of pollution in estuaries and lakes (NRC 2008). There are vast arrays of BMPs that can be effective in the managing pollutants. BMPs also have the added benefit of increasing infiltration and reducing overland flows. Implementation of more effective BMPs at the community level can help reduce the impact of climate change on storm water runoff.

While the impact of climate change on watershed systems is well studied (Rahman et al., 2015; Ekness and Randhir, 2015; Luo et al. 2013; Marshall and Randhir, 2008), research on the efficiency of BMPs to mitigate these impacts is limited. The focus on subbasin-scale management options to reduce stormwater impacts from climate change is unique in the study. This need in research is critical in developing adaptation strategies that are local and site-specific to subbasins.

This study assesses the impacts of climate change on stormwater runoff in a coastal watershed and evaluates the impacts of BMP's to evaluate adaptation strategies at subbasin scale. We focus on hydrologic changes in the watershed ecosystems that result from climate change. In summary, this paper is unique in studying climate change impacts on watershed systems in near and far-future scenarios and in exploring opportunities for adaptation through targeted BMPs at subbasin scale using simulation modeling. The Ipswich Watershed is a focus of this study because 
of its severity in low flow conditions and poor water quality. The U.S. Environmental Protection Agency (USEPA) has identified the river as stressed and lists this river as impaired (under Clean Water Act's 303d list).

Specific objectives are to: (1) Simulate baseline hydrologic conditions in the study watershed; (2) Examine the effects of near future and far-future climate change scenarios on watershed processes; and (3) Investigate the adaptation strategies using targeted placement of BMP's. The hypotheses specified are: (i) Climate change in near and far-futures have significant effect on water quality and quantity of watersheds; and (ii) targeted BMPs in subbasins scale can be useful in adapting to climate change.

\section{Methods}

In this section, we provide an overview of the study area, conceptual and empirical models, and methods used in research.

\section{Study Area:}

The study area is the Ipswich River watershed (Figure1). The Ipswich River Watershed is located in northeastern Massachusetts and flows from its headwaters in Burlington, Wilmington and Andover, until reaching Plum Island Sound of the Atlantic Ocean in the town of Ipswich (Figure 1). The river meanders and has a relatively flat course especially toward the end of the reach as it approaches the Ipswich Bay area. From the Ipswich headwater to the river's mouth, the elevation change is only about 35 meters over about 64.37 kilometers and has a drainage area of 401.45 square kilometers. The river itself is 56 kilometers long and with its 45 tributaries, it covers an area of about 401.45 square kilometers. The Ipswich watershed has approximately 160,000 people that reside within its boundaries and includes all or portions of 21 towns (IRWA, 2013). 
The Ipswich River has a history of problems with low flows and only recently has the watershed begun to improve. The American Rivers labeled the Ipswich River as the third most endangered river in 2003 (American Rivers Organization, 2003). The river is at a continually low state during the summer months as well going dry at multiple locations along the river. Through direct withdrawals from the river and excess ground water extraction, the river flows backwards at a particular location within the river.

The Ipswich watershed provides habitat for an array of wild life species including mammals, birds, amphibians, freshwater fish as well as anadromous fish. The forest of the Ipswich watershed is comprised primarily of white pine and mixed hardwoods, including red and white oak; sugar, red and silver maple; white ash, hickories and walnuts. There are considerable amounts of small mammals as well as larger ones including foxes, coyotes, bobcats, white tail deer, and moose (IRWA, 2013). The Ipswich river fish community is mostly generalist species that thrive in warm water and ponded conditions, as dams have changed the habitat available in the river. Seventy percent of the fish community is composed of three species: Redfin pickerel, American eel and Pumpkinseed. There are roughly 70 small dams and 500 crossings (culverts and bridges) in the river system, which has significantly altered the watershed from its natural conditions (IRWA, 2013). FTable in HSPF that defines channel geometry can model these structures.

\section{Conceptual Model:}

A conceptual model presents research flow in evaluating climate change effects on watershed systems (Figure 2). Climate change includes temperature and precipitation, and both these impact the watershed hydrology. The watershed is composed of physical attributes that, in 
turn, influence water quality and quantity. Adaptation strategy policies can mitigate changes in watershed hydrology.

\section{Simulation Model:}

We use Hydrological Simulation Program (HSPF) Version 2.3 (Aqua Terra, 2014) to model the watershed system. This simulation model is an integration of several early simulation models that include Stanford Watershed (Crawford, 1966), the Hydrologic Simulation Program Quality (Hydrocomp, 1977), and the Agricultural Runoff Management Model (Donigian et al, 1978), and other hydrological models (Borah, 2003). HSPF is a continuous simulation model of watershed hydrology and water quality for both conventional and toxic organic pollutants, as well as pervious and impervious land surfaces and in streams and well-mixed impoundments. The HSPF simulates the storage and movement of water, by routing watershed surface and river processes (Donigian et al, 1995). U.S. EPA recommends the HSPF model as one of the models for total maximum daily loads assessments nationwide (US EPA, 2014). The model is useful to analyze the long-term effects of hydrologic changes and water management practices (Borah, 2003). The model uses Philips method (Philips, 1969) and Chezy Manning equations (1975) to simulate infiltration (Migliaccio, 2007), and for overland runoff flows.

The shallow aquifer in the model considers active ground water storage and simulates fluctuations to deep percolation of ground water, ET, and baseflows. Kinematic wave equation (Migliaccio, 2007) models stream flow process. Other variables simulated in the model include soil and water temperatures, dissolved oxygen, carbon dioxide, nitrate, ammonia, organic nitrogen, phosphate and organic phosphorous. Woznicki and Nejadhashei (2012) studied the sensitivity of performance due to changes in precipitation, temperature and $\mathrm{CO}_{2}$ using the SWAT model. 
Water budgets are simulated on basis of hydrologic response units (HRUs) that characterize fluxes and storage in pervious and impervious areas of the watershed (Zarriello, 2009). HSPF contains three application modules (PERLAND, IMPLND, and RCHRES) and five utility modules that simulate hydrology/hydraulics and water quality processes of a watershed (Donigan et al. 1995). The general hydrologic budget is represented as: $\Delta S=B_{I}+P-I N F-$ $E T-Q-I N T-B_{O}$, where $\Delta S$ is storage; INF is infiltration, $B_{I}$ is the boundary input; $\mathrm{B}_{\mathrm{O}}$ is boundary output; $P$ is precipitation; $E T$ is evapotranspiration; $I N T$ is the interception; and $Q$ is surface runoff. The runoff is modeled using infiltration excess runoff from remaining precipitation after interception. These hydrologic routines are adapted from the Stanford watershed model (Bicknell et al. 1993) which include interception, evapotranspiration, runoff, interflow, baseflow, detension storage, soil moisture and routing (Donigan et al. 1984). Infiltration is modeled using Philips equation (Philips, 1957). Infiltrated water is partitioned into interflow, lower zone storage, and baseflow. Evapotranspiration is modeled as time series of Potential Evapotranspiration (PET) to evaluate flux in actual evapotranspiration (Bicknell et al. 1993).

The Chezy-Manning's equation is modeled as: $\frac{d S}{d t}=I-O$; and $Q=\frac{1}{n} A R^{2 / 3} S_{0}^{1 / 2}$, where, $S$ is storage volume of water $\left(\mathrm{m}^{3}\right) ; I$ is inflow rate $\left(\mathrm{m}^{3} \mathrm{~s}^{-1}\right) ; O$ is outflow rate $\left(\mathrm{m}^{3} \mathrm{~s}^{-1}\right)$ and accounts for runoff delay from friction and atershed shape (Bicknell et al. 1993). A detailed description of HSPF routines are presented in Bicknell et al. (1993).

The HSPF model separates watershed into three hydrologic elements: pervious land (PERLND), impervious land (IMPLND), and stream channels (RCHRES). The degree-day method assesses any accumulation of snow (U.S. EPA, 2001). Air temperature, wind, solar radiation, humidity, cloud cover, tillage practices, point sources, and pesticide applications are some of inputs in water-quality simulation. Physical measurements of the watershed are required to 
describe the land area, channels, and reservoirs, primarily through the digital elevation layer. We manually incorporated some of the manmade impairments (like dams) into the model as changes in parameters to the FTable. We use automatic delineation method with digital elevation layer of the region (Parker, 2012) and the total simulation period is 46 years. The GIS data for the model has a resolution of 30mx30m spatial scale for input files and modeled as hydrologic units (land use soils combination). We simulated the model at hourly time-step and generated outputs for weekly, monthly, and yearly scales for calibration.

\section{Calibration:}

We calibrated the model using the standard procedures suggested in HSPF calibration technical note and comments on sensitivity of each parameter (U.S. EPA, 2000). Specific calibration parameters (Table 1) include Lower Zone Nominal Soil Moisture Storage (LZSN), Infiltration Capacity (INFILT), Groundwater Recession (AGWRC), the Upper Zone Nominal Soil Moisture storage (UZSN), Interflow Inflow parameter (INTFW) and Lower Zone ET parameter (LZETP). The baseline model is calibrated and validated using observed streamflow information from four USGS gauging stations (hydrologic unit - code, 01101300, 01101344, 01101500, and 01102000) using HSPEXP+ (Aqua Terra, 2014) to evaluate the error structure for calibration. Calibration parameters include Lower Zonal Storage Number, Mean Soil Infiltration Rate, and Lower Zone Evapotranspiration (Table 2). Depending on the percent error, we calibrated the model parameters to minimize the error. This calibration process involves several reruns of simulations with calibrated parameter sets to identify the best model fit. The baseline model is calibrated with historic data and this baseline calibrated parameters are assumed to not change in future. This is also checked for any drastic sensitivity of parameters during the HSPFEXP+ runs. We tested the relationship between estimated and simulated values using regular $\mathrm{R}^{2}$ and Nash- 
Sutcliffe model efficiency (Nash 1970). The $\mathrm{R}^{2}$ value indicates how well the simulated data predicts observed data series. The Nash-Sutcliffe efficiencies vary from $-\infty$ to 1 and higher efficiencies indicate closeness of simulations to observed data. The Nash-Sutcliffe model

efficiency coefficient $(E)$ is calculated as: $E=1-\frac{\sum_{t=1}^{T}\left(Q_{0}^{t}-Q_{m}^{t}\right)^{2}}{\sum_{t=1}^{T}\left(Q_{0}^{t}-\overline{Q_{2}}\right)^{2}}$, where $Q_{\mathrm{o}}$ is the mean of observed discharges, $Q_{m}$ is the modeled discharge, and $Q_{0}{ }^{t}$ is observed discharge at time $t$. The model is validated internally using observed data at observations from selected subbasins. We use this calibrated and validated baseline model to simulate the impacts of climate change and adaptation potential using selected BMP scenarios. We used an infiltration BMP design of ponding reservoir type, specifically Bioretention/ Raingarden structural BMP. Bioretention / raingarden BMPs are designed in this study as this BMP is feasible and a recommended practice by environmental agencies for handling stormwater runoff in the region.

\section{Climate Change Scenarios:}

Climate change scenarios of IPCC (AR5) use representative concentration pathways (RCPs) for different categories based on severity, probability and location. We use the scenario RPC 4.5 in this study as it represents the most likely scenarios for the Northeast. The time intervals used for this project have a starting period for the baseline model at 1960 and continues to 2006. Near future and far future years used are 2035 and 2065 (WG1AR5, 2013). We developed six separate model scenarios: baseline, near-future climate, far-future climate, baseline with BMPs, near-future climate with BMPs, far-future climate with BMPs. Each of these scenarios represents combinations of climate change and adaption strategies of BMPs as green infrastructure in the watershed.

For climate scenarios in the model, we use the IPCC (WG1-AR5) predictions of precipitation and temperature for the northeastern United States, along with meteorological time 
series (IPCC, 2013). We compared these future scenarios to the baseline model, especially on how climate change would affect stormwater. We added the IPCC's percentage change in precipitation and temperature to the hourly time series of temperature and precipitation that is detrended for 1960 to 2006 . We add the percentage changes in precipitation and temperature uniformly to each of the segmented zones that define influence of each meteorological station defining the weather and climate of the watershed. Given a relatively smaller size of the watershed, uniform application is reasonable as climate change prediction are at a coarser scale. The second scenario that included the near future had a 3 percent increase in precipitation and a $1.1^{\circ} \mathrm{C}$ increase in temperature. The third scenario is the far-future scenario, which has an increase of precipitation by 5 percent and an increase in temperature of $2.1^{\circ} \mathrm{C}$. Time series data is processed and imported into HSPF model using the Sarah Time Series Utility (Aqua Terra Consultants, 2014).

\section{Targeted BMPS:}

To model scenarios with BMPs for storm water mitigation, the HSPF BMP web toolkit is used (U.S. EPA, 2014). Several BMP's are available to improve water quality and quantity, and the adaptation approach used for this project is use of bioretension/rain gardens that are infiltration BMPs of ponding reservoir type. We used the Green Infrastructure Tool (U.S. EPA, 2014) to edit individual reaches by altering the F-tables that govern stream dimensions in the HSPF model. We specify BMP dimensions based on the area of subwatershed through changes to the $F$-tables to simulate the BMPs in selected subwatersheds in the study area. In total, there are 43 new $F$-tables generated to simulate the use of BMPs in the watershed. We specify $F$-tables into five distinct sizes, based on the extent of urban area of each subbasin. A $T$-test is used to measure the significance in mean difference presented in table as $d f, T$-stat, $P(T<=t)$ one-tail, $T$-critical onetail, $P(T=t)$ two-tail, and $T$-critical two-tail. The F-test presents as the mean, variance, $d f, F$, 
$P(F<=f)$ one-tail and $F$-critical one-tail. We use T-test for the significance of the difference between the mean outcomes between two scenarios and F-test to test the difference in variances in distribution of the two scenarios.

The areas treated with BMP's are selected based on significant amounts of impervious coverage and having at least 30 acres in area. After these new reaches are simulated, we replace them with one of five distinct $F$ tables based upon the amount of urban area in the subbasin. These steps are then repeated for the baseline, near-future, and far-future scenarios. We estimated a number of statistics to compare the significance between scenarios, which include mean, standard error, median, standard deviation, sample variance, kurtosis, and skewness (Table 3).

\section{Data:}

Spatial data is from BASINS 4.1 (Better Assessment Science Integrating point and Nonpoint Sources) (USEPA, 2011). The USGS monitoring data from automated gage stations for the past 50 years is used for calibration and validation of the simulation model. This historical stream flow data is used to develop a baseline model of the watershed hydrologic process. Meteorological data is from NCDC (NOAA). The US Geological Survey -National Water Information System for weather is also used. The meteorological stations include Haverhill, Middleton, Reading, and Lawrence of Massachusetts. The land use layer is from the MassGIS dataset (MassGov, 2005). The soil layer used is State Soil Geographic Database - STATSGO2 (USDA, 2006). The General Circulation Model (GCM) scenarios for climate trajectories are from the IPCC Assessment Report 5 (IPCC, 2013).

\section{Results and Discussions}


Calibration: The simulated model fitted well with observed data for all intervals of time including days, months and years (Table 2). Daily simulations show an $\mathrm{R}^{2}$ of 0.73 with an NS value of 0.71 , which indicate a good explanatory power of the simulation model for daily variation in flows. Monthly simulation have an $\mathrm{R}^{2}$ of 0.82 and an NS value of 0.82 , indicating that the simulation model has good explanatory power in monthly and seasonal variations in flows. Yearly simulations have an $\mathrm{R}^{2}$ of 0.93 and an NS of 0.88 , a good fit in explaining inter-year variability in flows. Figures 3 to 5 shows the scatter plot and time-series plot of calibrations for daily, monthly, and yearly time steps. Scatter plots show a good match of observed and simulated data. The timeseries overlay between observed and simulated show a match in scale, direction, and variations.

Baseline: The study watershed has an average annual flow of $227 \mathrm{cfs}(6.44 \mathrm{cms}-$ cubic meters per second) with a high variability of $300 \mathrm{cfs}(8.5 \mathrm{cms})$ in standard deviation. The skewness value shows that the distribution of flow values is asymmetric and positively skewed. This indicates higher frequency of flows with lower values and a lower frequency (longer tail) for large flow values. As in Figure 7 (a), seasons play a critical role in the volume of flows. Similar results were obtained by Marshall and Randhir (2008). The months of June, July, August and September have the highest number of low flows - a target for improvement in river flows. A number of reasons including reduced precipitation, heat from impermeable surfaces, and excessive water withdrawals, can cause these low flows. Figure 6 (a) shows the parameters for the Ipswich River Basin for the baseline model. The largest value in this Figure shows potential evaporation with over 20 inches $(50.8 \mathrm{~cm}$ ), while interflow is the smallest. BMPs reduce surface runoff (Liu et al, 2015; Randhir and Raposa, 2014), while increasing groundwater recharge through interflow and baseflow. Baseline flows are compared to each scenario of climate change and to check the effectiveness of BMP's. The mean values for both the near future scenario and the far-future 
scenario are greater than the baseline. With addition of BMP's, storm water flows under each scenario reduced from baseline levels. Similar results were obtained by Liu et al (2015).

\section{Runoff change at different time scales:}

By analyzing the runoff on annual, monthly and weekly bases, we assess the effects of climate change on runoff at each of these time-scales.

Annual: The baseline annual flow was about $225 \mathrm{cfs}(6.37 \mathrm{cms})$ annually, while the far future scenario was $300 \mathrm{cfs}(8.5 \mathrm{cms})$ annually (Figure 6a). This difference may be a result of increased future precipitation in the watershed. Figures $6 b$ and $6 c$ show percent changes from baseline for each of scenario $b$ and $c$. In Figure $6 b$, the near future scenario shows an expected increase of $4 \%$ in flows, which can be mitigated through BMPs to $1 \%$ decrease from baseline level. In Figure $6 \mathrm{c}$, the far-future scenario shows a $24 \%$ increase in flow from the baseline. However, when the BMPs are implemented, there is only a $20 \%$ increase from the baseline. This indicates the need for other management measures to decrease the future increase in runoff.

Monthly: The average monthly flow for near future (Figure 7a) and for far future (Figure 7b) show specific pattern. It is observed that all months are affected by climate change, although some months are more affected than others depending on the type of climate scenario. We observe that under all scenarios with BMPs, impact of climate change on flows is lower than without BMPs. The percentage of change from the baseline (Figure 7c) that is a seasonal influence of the effects of climate change in both near and far future scenarios (Figure 7d). The near- future scenario has increases range from $1 \%$ to $9 \%$ increase from baseline levels with May being the highest increase and March having the least increase (Figure 7c). Winter months of January and February can expect a slight decrease ( $<1$ percentage) in flows from the baseline. This highlights the seasonal and monthly variability in the effects of climate change effect on the watershed. Under far-future 
climate scenario, all months exceeded at least $15 \%$ increase in flows from the baseline scenario. With the addition of BMPs to near-future scenario, there was a decrease of $1 \%$ to $5 \%$ in flows below baseline levels for all months. With the addition of BMPs to far-future scenario, there was a $1 \%$ to $4 \%$ decrease in flow for all months. This indicate that BMPs are effective in reducing storm flow impacts of near future during all months. BMPs can also mitigate to some extent the increased storm flow in all months from climate change under far-future scenario and need to augment with other stormflow reduction strategies.

Weekly: Storm water flows on a weekly and a monthly scale is useful in capturing the intra-year and seasonal changes in a year. Figure 8 presents the average weekly flows for the entire period. In Figure 8a, we observe a moderate increase in near-future flows from the baseline and the BMPs are affective mitigating incremental flow in all weeks. Average flows in some weeks has higher increment from the baseline than other weeks. For example, weeks 10 through 19 (March to early May) have a greater increase in flow than weeks 29 to 37 during June to August. Comparing different time scales, it is evident that seasonal changes in monthly and weekly time scales is important to consider in evaluating impacts on storm water flows. With the implementation of BMPs, there is a reduction in future climate impacts on weekly flows. In addition, the reduction expected from BMPs vary between the two future scenarios (Figure 8). It is evident that during some weeks, BMPs are more effective than other weeks. This is useful information in adapting watersheds to climate change impacts. Mitigation of seasonal variability and reduction in specific flow events through BMPs can allow stable hydrologic conditions in the watersheds exposed to climate change. In general, BMPs can be effective in both near and far- future scenarios of climate change, when compared to scenarios without the BMPs. To reduce increase in flows fully, there is a need to increase BMPs coverage and to supplement with other strategies. 
Weekly impacts show the extent of runoff variability and mitigation opportunity with BMPs at a smaller time scale. Monthly changes show seasonal impacts and effectiveness of mitigating climate impacts that shift seasonal changes in runoff. Annual impacts show general trends over long run and BMP effectiveness to mitigate climate impacts on inter-annual fluxes.

Changes in annual water balance: Figure 9a, shows the baseline levels of various components of the water budget in the watershed. The largest component in the baseline is potential evapotranspiration, followed by the baseflow. Climate changes can affect the watershed's ability to store water for longer periods as ground water. Soils types have limitations on the amount of water that can infiltrate the soil with the increase in rain intensity caused by climate change. This process can be exacerbated by increased precipitation occurring in intense intervals or increase in impervious surfaces within the watershed. Figure 9 presents the effects of climate change with major increases in runoff under each of the future scenarios. BMPs such as rain gardens allows increase in infiltration rate of precipitation. Figure $9 \mathrm{~b}$ shows the percent change from the baseline under near-future scenario. The flows from impervious surfaces had the greatest reduction to $3 \%$ below the baseline levels with the use of BMP's. In Figure 9c under the far-future scenario, BMP's result in a reduction of $6 \%$ in flows from impervious surface.

\section{Statistical Analysis:}

The statistics for each scenario (Tables 4 \&5) include mean, standard error, median, standard deviation, sample variance, kurtosis, and skewness. There was a higher increase in the mean and variability of the far-future scenario compared to near future scenario. In all scenarios, the implementation of BMPs reduced mean flows to some extent. With the BMPs in place in the near-future, the mean and variability in flow reduced compared to baseline levels. This demonstrates that BMPs are very effective in reducing flow in the near-future scenario. As 
expected in situation dealing with flow data dispersed over a large period, the standard deviation for flows in each scenario is quite large. The Ipswich River flows can vary greatly during the season. The kurtosis was positive for all scenarios indicating that there was peaked distribution. The scenario results indicate a positively skewness of the distribution (Table 3).

We use statistical F-test and the T-test to test the significance of results under each of the scenarios compared to the baseline (Tables 4 and 5). The T-test significance if for difference between means of baseline and other scenario outcomes. Under F-Test, the significance is for differences in variance in distribution of baseline and scenario outcome. The variance also reduced through implementation of the BMPs. This indicates that adaptation of watershed system can reduce the variability in storm water events. The Pearson Rank Correlations for each of the scenarios comparisons were positive.

Our results are consistent with literature (Marshall and Randhir, 2008; Zahmatkesh et al. 2014) in assessing the impacts on climate change on runoff in the watershed. Our results also agree with literature (Dakhlalla and Parajuli, 2015; Randhir and Raposa, 2015; Jia et al. 2015) on the role of BMPs in mitigating runoff impacts of climate change. In summary, climate change could have significant impact on watershed processed of the Ipswich River watershed. Targeted BMPs at the subbasin scale can be an adaptation strategy to mitigate climatic impacts. The need for designing BMPS that are scale optimal is useful to reduce stormwater impacts of climate change.

Policy Implications: Impact of climate change on watershed ecosystems are complex, needing careful assessment and adaptation efforts. Mitigating storm water impacts of climate change in the watershed is important under both near and far-future scenarios. In general, BMPs are effective in mitigating these effects with optimal installation and maintenance. We assume that these optimal 
conditions are accounted in BMP installations in all scenarios. Without maintenance there is a likelihood of sediment deposition reducing the infiltration and ponding capacity of the BMP. The BMP simulated in this project is the bioretention/rain garden, a popular storm water BMP in the region. Incentives to implement BMPs can include cost-sharing schemes, tax rebates, and subsidies for voluntarily adoption of BMPs. One could design markets for storm water permits at watershed scale to reduce increase in storm water issues that result from climate change. Education to municipalities, residents and landscapers on BMPs like native plant gardens, green roofs, permeable paving and rain gardens (IRWA, 2013) can increase resilience of watershed to climate change. The long-term financial implications of selected BMPs are difficult to measure in terms of their effectiveness. The net present costs of different BMPs are often proportional to the density of their use (Urbonas and Olson, 2011. The green infrastructure strategies can be cost-effective when compared to conventional storm-water management approaches, when looking at their direct costs and savings over their lifetime (Jaffe, 2010).

\section{Conclusion}

Climate change can have significant impacts on the hydrologic processes of a watershed system. Storm water runoff is particularly sensitive to climate change and its response could vary over time and space. There is a need for evaluating these impacts at a watershed scale for developing effective strategies in order to mitigate these impacts. Using simulation modeling with HSPF, this study projects the future effects of climate change under near-future and far-future scenarios to evaluate expected changes from baseline levels and potential for BMPs to mitigate the impacts. We observe an increase in storm water volume and variability under near and far-future climate change scenarios. The spatial and temporal patterns in these flows are also significant in 
the watershed system. Climate impacts vary at multiple time scales, which highlight the influence on daily variability, seasonality, and inter-year trends. The impacts also vary by subbasin with influence depending on land use, soils, topography, and hydrography that influence storm water runoff. In general, Targeting BMPs at subbasin scale is useful mitigating increased storm water in near future scenario. There is a general reduction in the variability of storm flows with incorporation of BMPs under both climate change scenarios. There is a need for more extensive adoption of BMPs along with storm water strategies to address impacts of far-future climate.

Targeted approach require use of local information in designing policies that increase resilience of the watershed to climate change. Information provision is an important policy tool that is useful in encouraging voluntary adoption of BMPs. In addition, land use plan for towns and municipalities could incorporate resilience to mitigate climate change impacts in vulnerable zones of the watershed. Changes in zoning laws to regulate land use are useful in reducing future resilience of the watershed. Storm water fees as a tax could encourage voluntary adoption of BMPs in regions that have potential to generate higher volume of runoff for a typical storm event. Indicators could be impervious cover, absence of BMPs, and vulnerability of the land parcel. Subsidizing BMPs through cost sharing and tax rebates can act as incentives to mitigate storm water runoff.

The study develops an integrated approach to use mathematical modeling to study climatic impacts on watershed systems and assessment of BMPs. There is a need for further research into studying water quality impacts of climate change in the watershed. In addition, there is scope to increase monitoring in the watershed for higher resolution of datasets. Climate change impacts can be significant on watershed systems and there is a need for continuous monitoring and modeling of ecohydrologic processes impacted by climate change. 


\section{References}

American Rivers Organization, 2003. America's most endangered rivers of 2003: Ten rivers reaching the crossroads in the next 12 months. http://www.americanrivers.org/wpcontent/uploads/2014/02/MER_2003.pdf?6fda73

Aqua Terra Consultants, 2014. Downloads and software.

URL:http://www.aquaterra.com/resources/downloads/index.php

Arnell, N.W. and Gosling, S.N., 2013. The impacts of climate change on river flow regimes at the global scale. Journal of Hydrology, 486, pp.351-364.

Bicknell, B.R., J.C. Imhoff, J.L. Kittle Jr., A.S. Donigian, Jr. and R.C. Johanson. 1993. Hydrological Simulation Program - FORTRAN. User's Manual for Release 10. EPA/600/R93-174. U.S. EPA Environmental Research Laboratory, Athens, GA.

Borah, D.K. and M. Bera, 2003. Watershed-Scale Hydrologic and Nonpoint-Source Pollution Models: Review of Mathematical Bases. American Society of Agricultural Engineers, 44 (6), 1553-1566. http://www.isws.illinois.edu/iswsdocs/journals/TransASAE46-6-1553-1566.pdf

California Climate Adaptation Strategy, 2009. California Natural Resources Agency. http://resources.ca.gov/climate_adaptation/docs/Statewide_Adaptation_Strategy.pdf

Dakhlalla, A.O. and Parajuli, P.B., 2016. Evaluation of the Best Management Practices at the Watershed Scale to Attenuate Peak Streamflow Under Climate Change Scenarios. Water Resources Management, 30(3), pp.963-982.

Döll, P. and Schmied, H.M., 2012. How is the impact of climate change on river flow regimes related to the impact on mean annual runoff? A global-scale analysis. Environmental Research Letters, 7(1), p.014037.

Donigan, A.S., B.R. Bicknell., and J.C. Imhoff. 1995. Hydrologic Simulation Program - Fortran (HSPF). In: Singh, V.P. (Ed) Computer Models in Watershed Hydrology. Water Resources Publisher, Colorado USA.

Donigian, A.S., Jr., J.C. Imhoff, B.R. Bicknell and J.L. Kittle, Jr. 1984. Application Guide for the Hydrological Simulation Program - FORTRAN EPA 600/3-84-066, Environmental Research Laboratory, U.S. EPA, Athens, GA. 30613.

Ekness, P. and Randhir, T.O., 2015. Effect of climate and land cover changes on watershed runoff: A multivariate assessment for storm water management. Journal of Geophysical Research: Biogeosciences, 120(9), pp.1785-1796. 
Fritze, H., I. T. Stewart, and E. Pebesma, 2011. Shifts in western North American snowmelt runoff regimes for the recent warm decades. Journal of Hydrometeorology, 12:989-1006.

doi:10.1175/2011JHM1360.1

Geosyntec Consultants, Inc. and Wright Water Engineers, Inc., 2014. International stormwater Best Management Practices (BMP) database pollutant category statistical summary report: solids, bacteria, nutrients, and metals. http://www.bmpdatabase.org/Docs/2012\%20Water\%20Quality\%20Analysis\%20Addendum/B MP\%20Database\%20Categorical_SummaryAddendumReport_Final.pdf

Hevesi, J.A., L.E. Flint, C.D. Church, and G.O Mendez, 2011. Using a watershed model (HSPF) to evaluate sources and transport of pathogen indicator bacteria in the Chino Basin, San Bernardino County, California. U.S. Geological Survey Scientific Investigations Report 2009-5219, 148. $\quad$ http://pubs.usgs.gov/sir/2009/5219/pdf/sir20095219.pdf

IPCC, 5th Assessment Report. 2013. Climate Change 2013 The Physical Science Basis. http://www.climatechange2013.org/images/report/WG1AR5_ALL_FINAL.pdf

Ipswich River Watershed Association (IRWA). 2013. The Voice of the River. www.ipswichriver.org/sustainable-water-management-initiative. Accessed 2013 10/14.

Jaffe, M. Reflections on Green Infrastructure Economics. 2010. Environmental Practice, 12 (4), 357-365. doi:10.1017/S1466046610000475

Jia, H., Yao, H., Tang, Y., Shaw, L.Y., Field, R. and Tafuri, A.N., 2015. LID-BMPs planning for urban runoff control and the case study in China. Journal of environmental management, 149, pp.65-76.

Liu, Y., Bralts, V.F. and Engel, B.A., 2015. Evaluating the effectiveness of management practices on hydrology and water quality at watershed scale with a rainfall-runoff model. Science of The Total Environment, 511, pp.298-308.

Luo, Y., D.L. Ficklin, X. Liu, and M. Zhang. 2013. Assessment of climate change impacts on hydrology and water quality with a watershed modeling approach. Science of the total environment, 450, pp.72-82.

Marshall E., and T. Randhir. 2008. Effect of climate change on watershed system: a regional analysis. Climatic Change. 89:263-280.

Matthews, T. 2011. Climate change adaptation in urban systems: Strategies for planning regimes. Urban Research Program. Griffith University, Brisbane, QLD 4111 (No. 32).

Migliaccio, K. W. and P. Srivastava, 2007. Hydrologic Components of Watershed-Scale Models.American Society of Agricultural and Biological Engineers, 50 (5), 1695-1703. http://trec.ifas.ufl.edu/kwm/documents/Migliaccio-Srivastava.pdf 
Murray, S. J., P. N. Foster, and I. C. Prentice, 2012. Future global water resources with respect to climate change and water withdrawals as estimated by a dynamic global vegetation model. Journal of Hydrology, 448-449, 14-29. doi:10.1016/j.jhydrol.2012.02.044

Parker, C., N. J. Clifford, and C. R. Thorne, 2012. Automatic delineation of functional river reach boundaries for river research and applications. River Research and Applications, 28, 1708-1725.

Philip, J.R. 1957. The theory of infiltration: 1. The infiltration equation and its solution. Soil Science. 83(5): 345-358.

Rahman, K., A.G. da Silva, E.M. Tejeda, A. Gobiet, M. Beniston, and A. Lehmann. 2015. An independent and combined effect analysis of land use and climate change in the upper Rhone River watershed, Switzerland. Applied Geography, 63, pp.264-272.

Randhir, T.O. and Raposa, S., 2014. Urbanization and watershed sustainability: Collaborative simulation modeling of future development states. Journal of Hydrology, 519, pp.1526-1536.

Urbonas, B. and C. Olson, 2011. Assessment of Stormwater BMP Cost Effectiveness. Stormwater: A Journal for Surface Water Quality Professionals, March-April, 1-8. http://www.stormh20.com/SW/Articles/Assessment_of_Stormwater_BMP_Cost_Effectivenes s_13836.aspx

U.S. Environmental Protection Agency, 2000. Estimating Hydrology and Hydraulic Parameters for HSPF. EPA BASINS Technical Note 6. EPA-823-R00-012 . http://water.epa.gov/scitech/datait/models/basins/upload/2000_08_14_BASINS_tecnote6.pdf

U.S. Environmental Protection Agency, 2001. Better Assessment Science Integrating point and Nonpoint Sources: BASINS version 3.0. EPA-823-B-01-001. http://water.epa.gov/scitech/datait/models/basins/upload/2009_04_03_BASINS_b3docs_user manual.pdf

U.S. Environmental Protection Agency, 2014. HSPF BMP Web Toolkit: Ecosystems Research Division. http://www.epa.gov/athens/research/HSPFWebTools/

U.S.G.S. Water Resources Applications Software. http://water.usgs.gov/cgi-bin/man_wrdapp?hspf Accessed 2014, August.

Williams, S., D. Newquist, S. Libes and S.G. Strickland, 2014. Watershed management planning for the Murrells Inlet Estuary using GIS: delineation, assessment, identification, and solutions for fecal coliform loading. Institute of Computational Ecology: 2014 Clemson University, South Carolina Water Resource Conference, http://tigerprints.clemson.edu/cgi/viewcontent.cgi?article=1303\&context=scwrc

Woznicki, S., and A. P. Nejadhashemi, 2012. Sensitivity analysis of best management practices under climate change scenarios. Journal of the American Water Resources Association, 48(1), 90-112. 
Zahmatkesh, Z., Karamouz, M., Goharian, E., and Burian, S. (2014). "Analysis of the Effects of Climate Change on Urban Storm Water Runoff Using Statistically Downscaled Precipitation Data and a Change Factor Approach." J. Hydrol. Eng., 10.1061/(ASCE)HE.19435584.0001064, 05014022.

Zarriello,P.J. 2009. HSPF and MODFLOW—Capabilities, Limitations, and Integration. IN Bent, G.C., Zarriello, P.J., Granato, G.E., Masterson, J.P., Walter, D.A., Waite, A.M., and Church, P.E., 2011, Simulated effects of water withdrawals and land-use changes on streamflows and groundwater levels in the Pawcatuck River Basin, southwestern Rhode Island and southeastern Connecticut: U.S. Geological Survey Scientific Investigations Report 20095127, 254 p., at http://pubs.usgs.gov/sir/2009/5127.

Zoppou, C. 2001. Review of urban storm water models. Environmental Modeling \& Software, 16(3), 195. 
Table 1 Selected calibration Parameters for permeable land

\begin{tabular}{|c|c|c|c|c|c|}
\hline OpNum & Land-use Types & $\begin{array}{l}\text { Soil } \\
\text { Type }\end{array}$ & $\begin{array}{l}\text { Lower Zonal } \\
\text { Storage Number } \\
(\mathrm{mm})\end{array}$ & $\begin{array}{l}\text { Mean Soil } \\
\text { Infiltration Rate } \\
(\mathrm{cm} / \mathrm{hr})\end{array}$ & $\begin{array}{l}\text { Lower Zone } \\
\text { Evapotranspiration } \\
\text { (Index) }\end{array}$ \\
\hline 101 & Agricultural Land & A & 177.8 & 1032 & 0.4 \\
\hline 102 & Forest & A & 228.6 & 10.32 & 0.6 \\
\hline 103 & Wetlands/Water & A & 304.8 & 10.32 & 0.5 \\
\hline 104 & $\begin{array}{l}\text { Barren Land } \\
\text { Agriculture- }\end{array}$ & A & $\begin{array}{c}76.2 \\
152.4\end{array}$ & 10.32 & 0.15 \\
\hline 105 & Pasture & A & 152.4 & 10.32 & 0.35 \\
\hline 106 & Urban & A & 127 & 10.32 & 0.1 \\
\hline 107 & Shrub land & A & 127 & 10.32 & 0.3 \\
\hline 108 & Agricultural Land & $\mathrm{C}$ & 177.8 & 1.29 & 0.4 \\
\hline 109 & Forest & $\mathrm{C}$ & 228.6 & 1.29 & 0.6 \\
\hline 110 & Wetlands/Water & $\mathrm{C}$ & 304.8 & 1.29 & 0.5 \\
\hline 111 & Barren Land & $\mathrm{C}$ & 76.2 & 1.29 & 0.15 \\
\hline 112 & $\begin{array}{l}\text { Agriculture- } \\
\text { Pasture }\end{array}$ & $\mathrm{C}$ & 152.4 & 1.29 & 0.35 \\
\hline 113 & Urban & $\mathrm{C}$ & 127 & 1.29 & 0.1 \\
\hline 114 & Shrub land & $\mathrm{C}$ & 127 & 1.29 & 0.3 \\
\hline 115 & Forest & D & 228.6 & 0.26 & 0.6 \\
\hline 116 & Wetlands/Water & $\mathrm{D}$ & 304.8 & 0.26 & 0.5 \\
\hline 117 & Urban & D & 127 & 0.26 & 0.1 \\
\hline 118 & Agricultural Land & D & 177.8 & 0.26 & 0.4 \\
\hline 119 & $\begin{array}{l}\text { Barren Land } \\
\text { Agriculture- }\end{array}$ & D & 76.2 & 0.26 & 0.15 \\
\hline 120 & Pasture & D & 152.4 & 0.26 & 0.35 \\
\hline 121 & Shrub land & $\mathrm{D}$ & 127 & 0.26 & 0.3 \\
\hline
\end{tabular}

Table 2 Calibration Statistics for daily, monthly, and annual flows

\begin{tabular}{l|c|c|c|c}
\hline & $\mathbf{R}^{\mathbf{2}}$ & Nash-Sutcliffe & $\begin{array}{c}\text { Simulated } \\
\text { Observed Mean } \\
\text { (Standard Error) }\end{array}$ & $\begin{array}{c}\text { Mean (Standard } \\
\text { Error) }\end{array}$ \\
\hline Day & 0.73 & 0.71 & $193.18(1.98)$ & $193.97(2.00)$ \\
Month & 0.82 & 0.82 & $193.68(8.46)$ & $182.68(7.52)$ \\
Year & 0.93 & 0.88 & $192.23(9.93)$ & $181.98(8.09)$ \\
\hline
\end{tabular}


Table 3 Scenario Statistics for Runoff under all Scenarios

\begin{tabular}{|c|c|c|c|c|c|c|}
\hline & \multicolumn{6}{|l|}{ Scenarios } \\
\hline & Baseline & Near Future & Far Future & $\begin{array}{l}\text { Baseline \& } \\
\text { BMP's }\end{array}$ & $\begin{array}{l}\text { Near Future \& } \\
\text { BMP's }\end{array}$ & $\begin{array}{l}\text { Far Future } \\
\& \text { BMP's }\end{array}$ \\
\hline Mean (cfs*) & 227.41 & 236.99 & 300.84 & 216.08 & 225.18 & 286.33 \\
\hline Standard Error & 2.30 & 2.38 & 2.89 & 2.16 & 2.24 & 2.73 \\
\hline Median & 146.82 & 152.92 & 193.41 & 139.79 & 146.20 & 185.11 \\
\hline $\begin{array}{l}\text { Standard } \\
\text { Deviation }\end{array}$ & 299.51 & 310.08 & 376.56 & 281.91 & 292.13 & 355.55 \\
\hline $\begin{array}{l}\text { Sample } \\
\text { Variance }\end{array}$ & 89711.17 & 96154.59 & 141802.81 & 79479.17 & 85342.59 & 126423.12 \\
\hline Kurtosis & 48.03 & 45.85 & 33.87 & 47.88 & 45.92 & 34.37 \\
\hline Skewness & 5.12 & 5.01 & 4.31 & 5.06 & 4.97 & 4.31 \\
\hline
\end{tabular}

$* 1 \mathrm{cfs}=0.0283168 \mathrm{cms}$

Table 4 Impact of BMPs on Runoff (Between Scenarios)

\begin{tabular}{l|l|l|r|r}
\hline Between Scenario & Mean (cfs*) & Variance & $\begin{array}{l}\text { Mean } \\
\text { difference } \\
\text { from } \\
\text { baseline (\% } \\
\text { of baseline) }\end{array}$ & $\begin{array}{l}\text { Significance } \\
\text { from } \\
\text { baseline }\end{array}$ \\
\hline $\begin{array}{l}\text { Base line } \\
\text { Near future }\end{array}$ & 227.41 & 89711.17 & 0.04 & -4.04 \\
Near Future + BMP & 236.99 & 96154.59 & -0.01 & 0.99 \\
Far future & 225.18 & 85342.59 & 0.32 & -24.41 \\
Far future + BMP & 300.84 & 141802.81 & 0.26 & -20.58 \\
\hline
\end{tabular}

$* 1 \mathrm{cfs}=0.0283168 \mathrm{cms}$

Table 5 Impact of BMPs on Runoff (Within Scenarios)

\begin{tabular}{l|l|l|l|r}
\hline Within Scenario & $\begin{array}{l}\text { Mean } \\
(\mathbf{c f s} *)\end{array}$ & Variance & $\begin{array}{l}\text { Difference } \\
\text { (\% from No } \\
\text { BMP } \\
\text { scenario) }\end{array}$ & $\begin{array}{l}\text { Significance } \\
\text { of BMP } \\
\text { scenario }\end{array}$ \\
\hline Baseline & 227.41 & 89711.17 & & 5.24 \\
Baseline + BMP & 216.08 & 79479.17 & -0.05 &
\end{tabular}




\begin{tabular}{l|l|l|l|l} 
Near future & 236.99 & 96154.59 & -0.05 & 5.24 \\
Near Future + BMP & 225.18 & 85342.59 & & \\
Far future & 300.84 & 141802.81 & -0.06 & 5.07 \\
Far future + BMP & 286.33 & 126423.12 & \\
\hline
\end{tabular}

$* 1 \mathrm{cfs}=0.0283168 \mathrm{cms}$

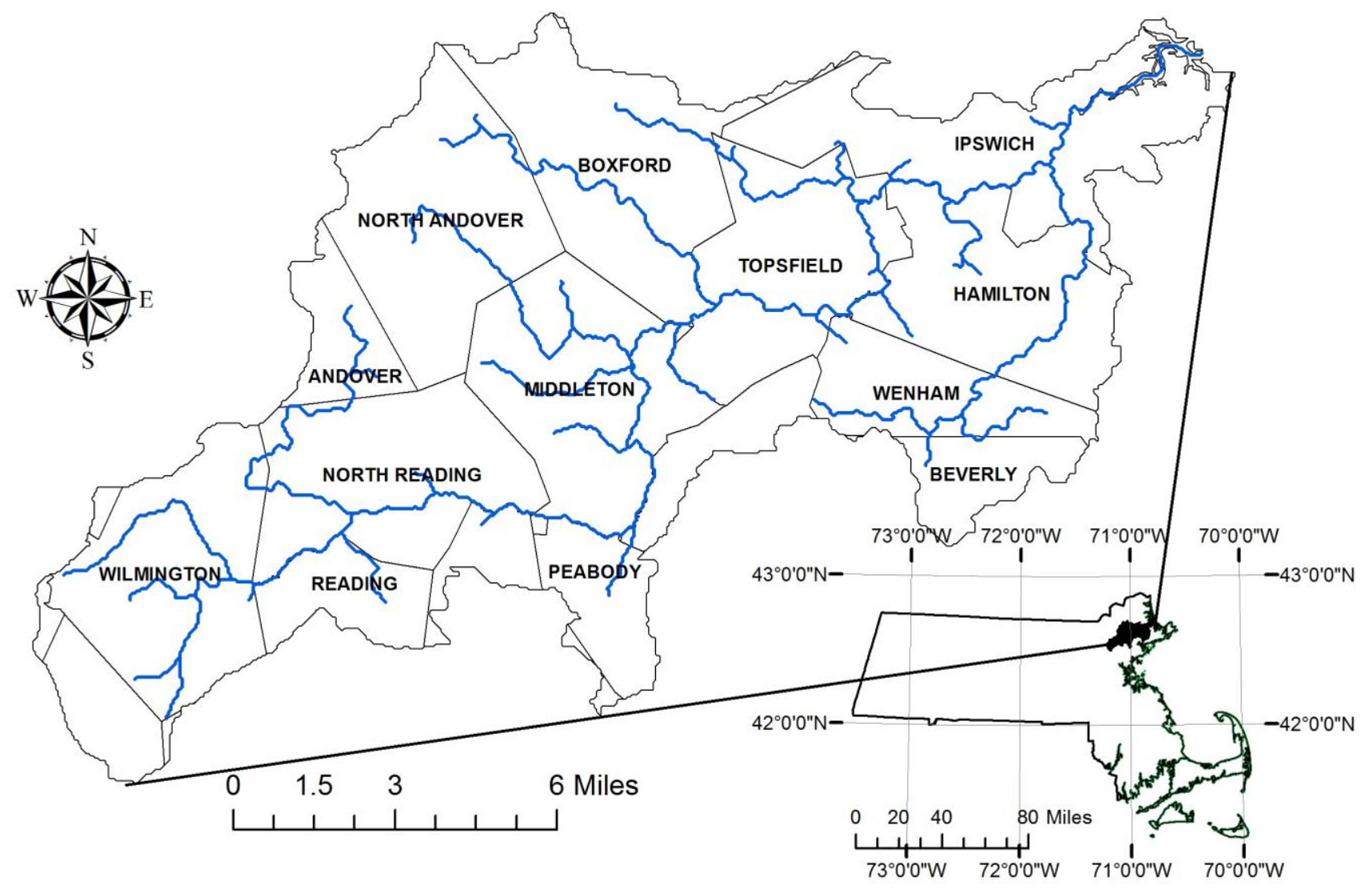

Figure 1. Ipswich River Watershed in northeast of Massachusetts 


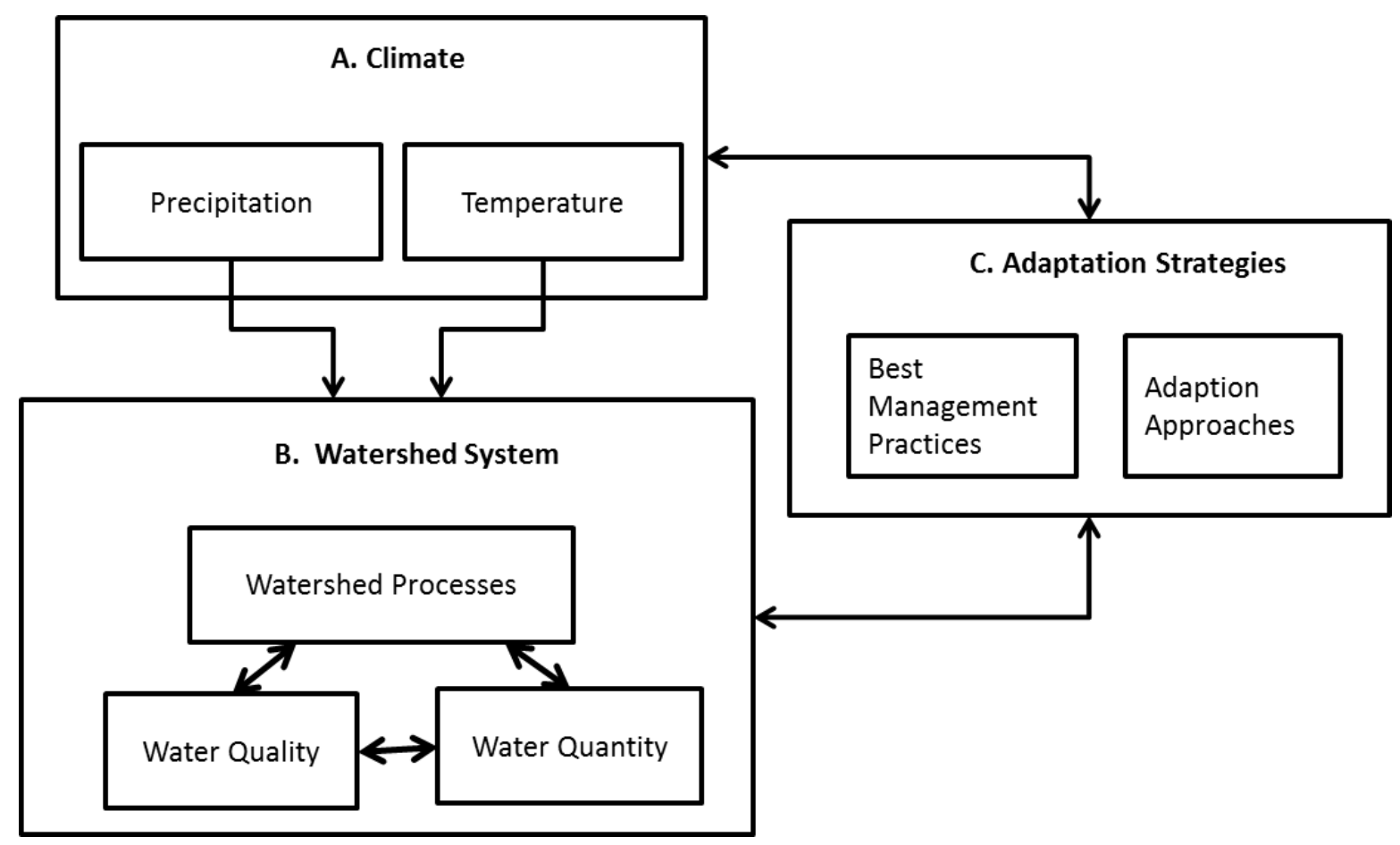

Figure 2. Conceptual Model of climate change impacts on watershed systems 


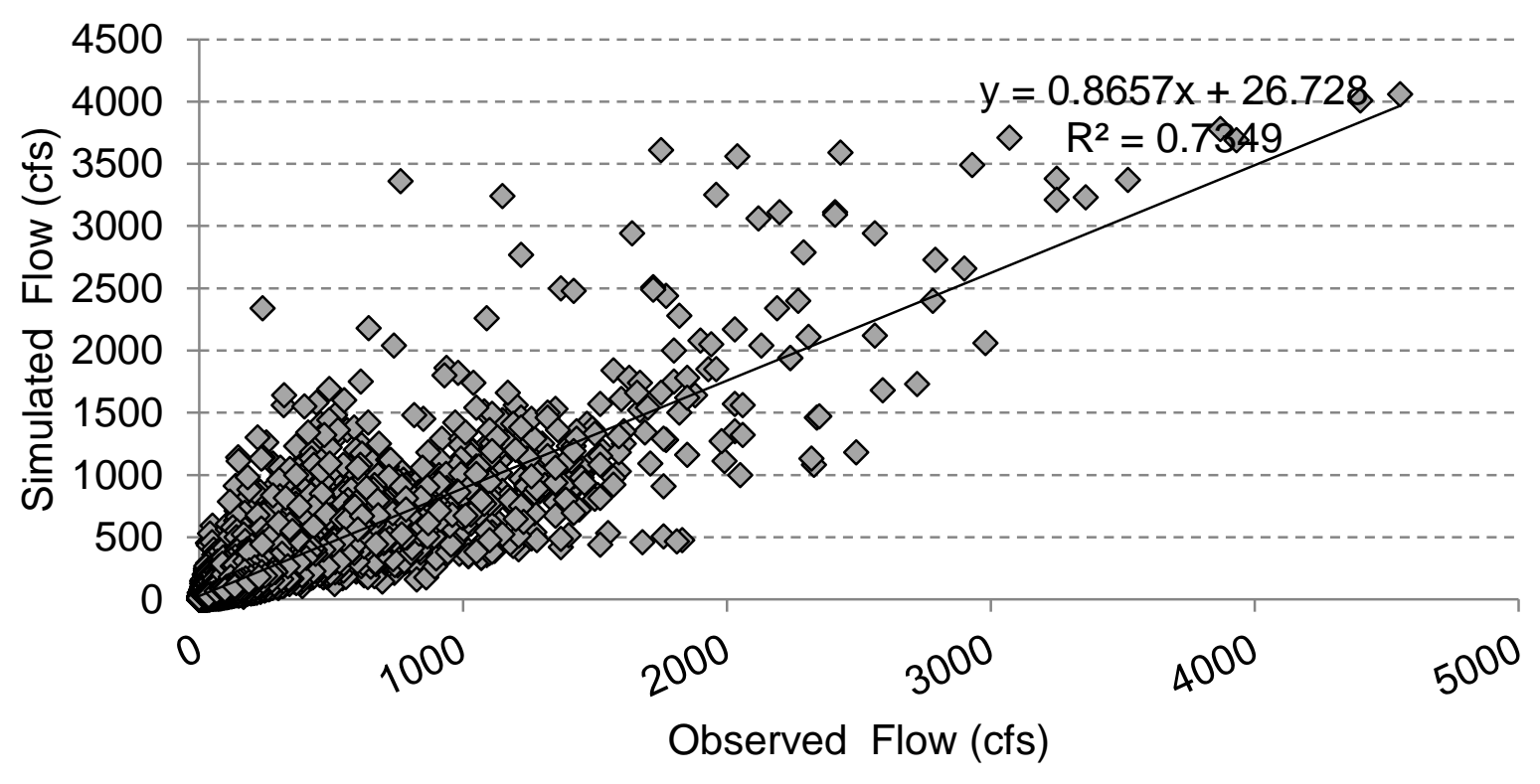

(a). Weekly regression

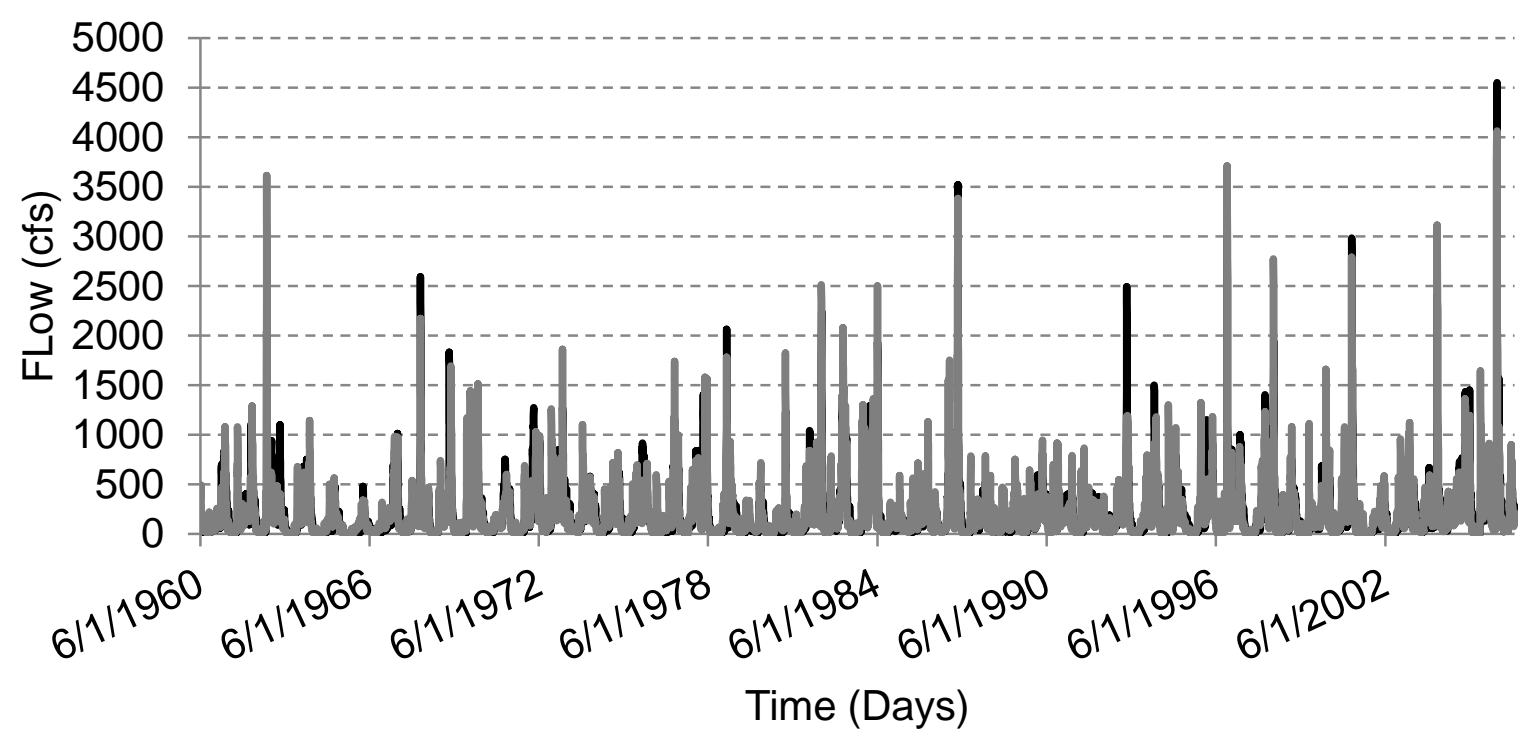

-Observed Data $\quad$ Simulated Data

(b) Weekly time series overlay

Figure 3. Calibration Results:(a) Observed Data Vs Simulated Flow Data (Days), (b) Time (Days) Vs Flow Data $(1 \mathrm{cfs}=\mathbf{0 . 0 2 8 3 1 6 8} \mathrm{cms})$ 


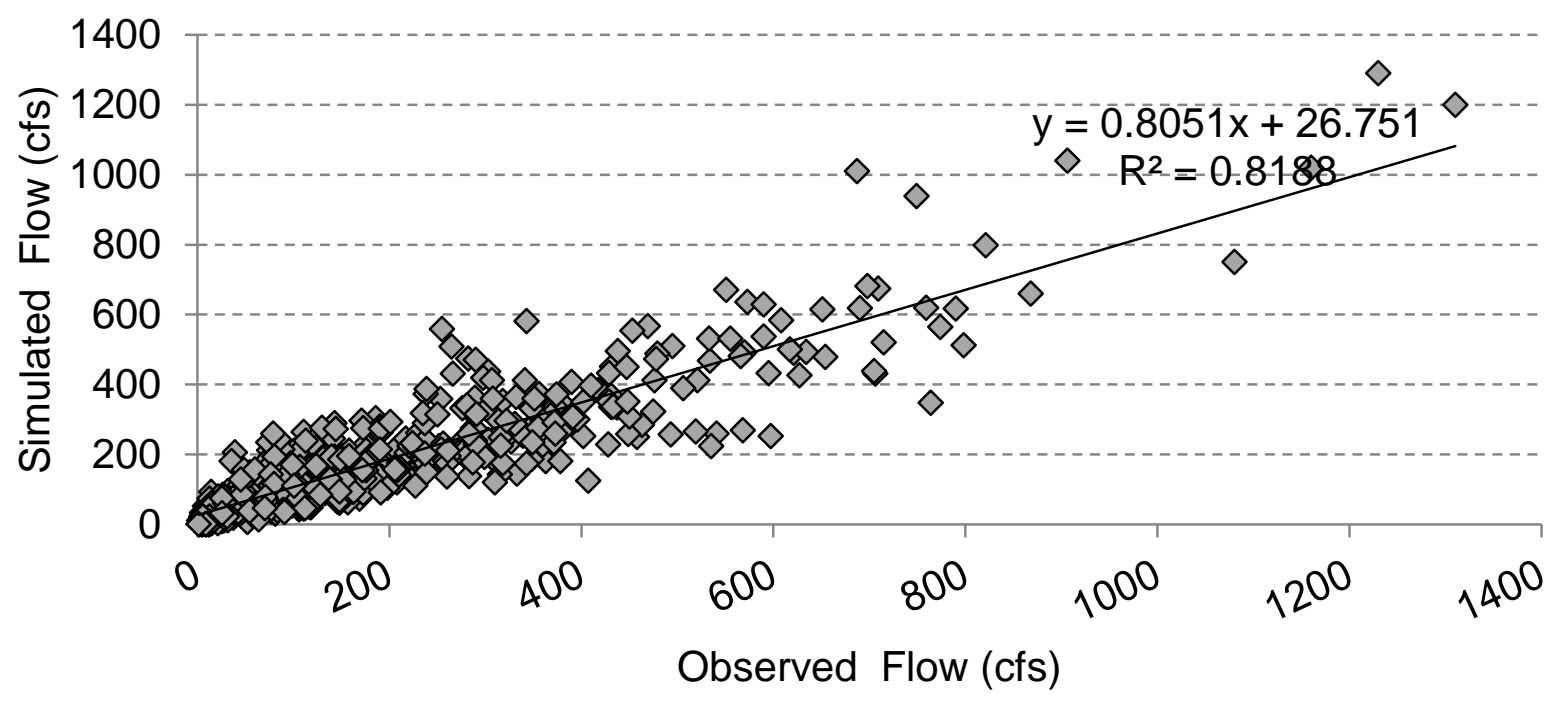

(a) Monthly regression

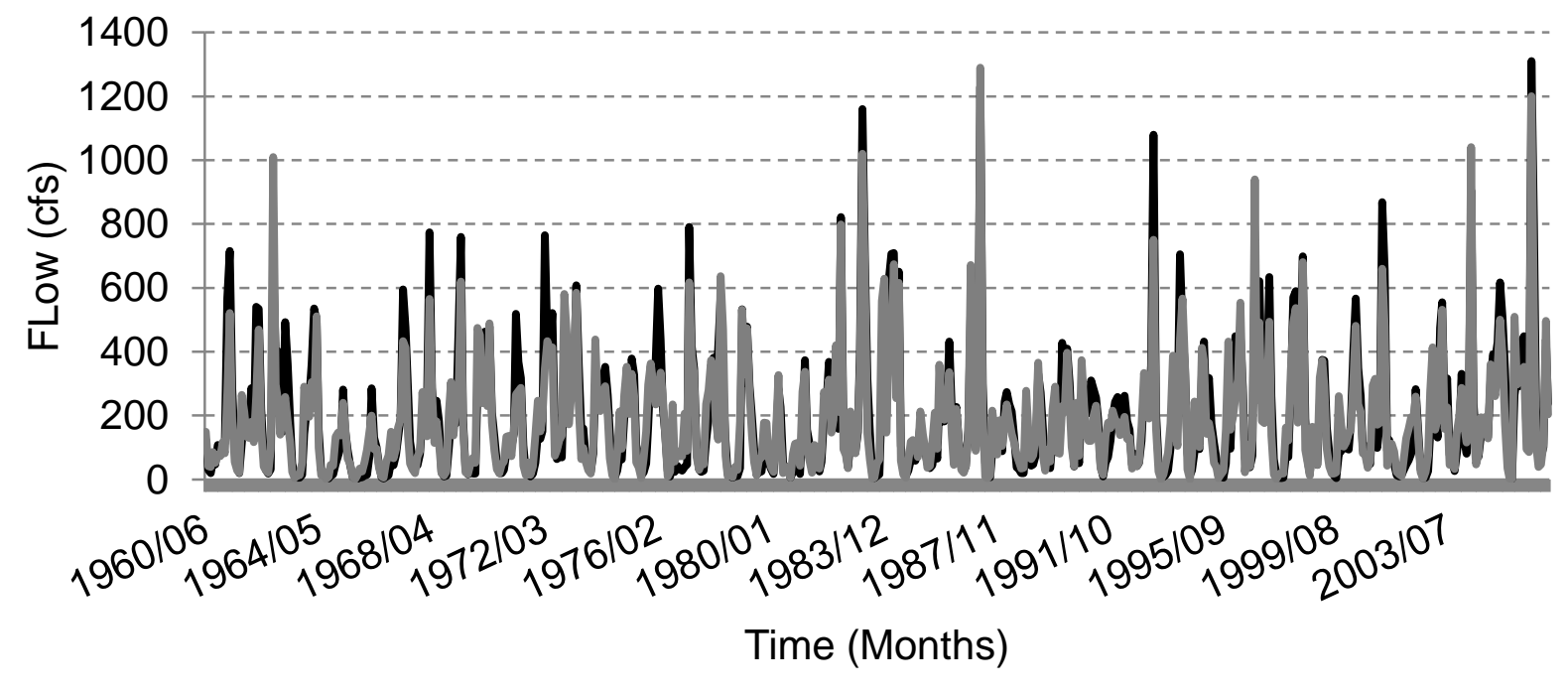

-Observed Data —Simulated Data

(b) Monthly time series overlay

Figure 4. Calibration Results: (a) Observed Data Vs Simulated Flow Data (Months), (b) Time (Months) Vs Flow Data $(1 \mathrm{cfs}=0.0283168 \mathrm{cms})$ 


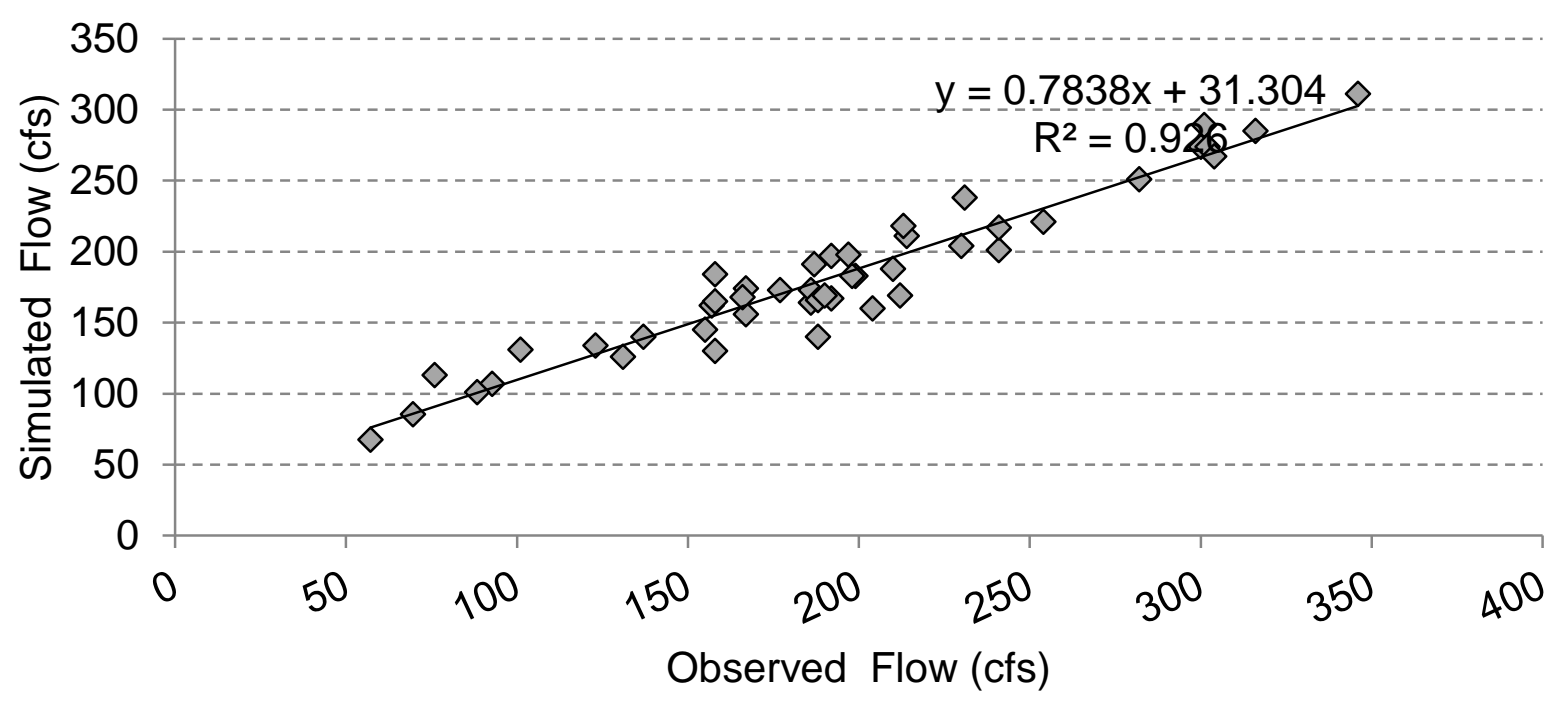

(a) Observed Data Vs Simulated Flow Data (years)

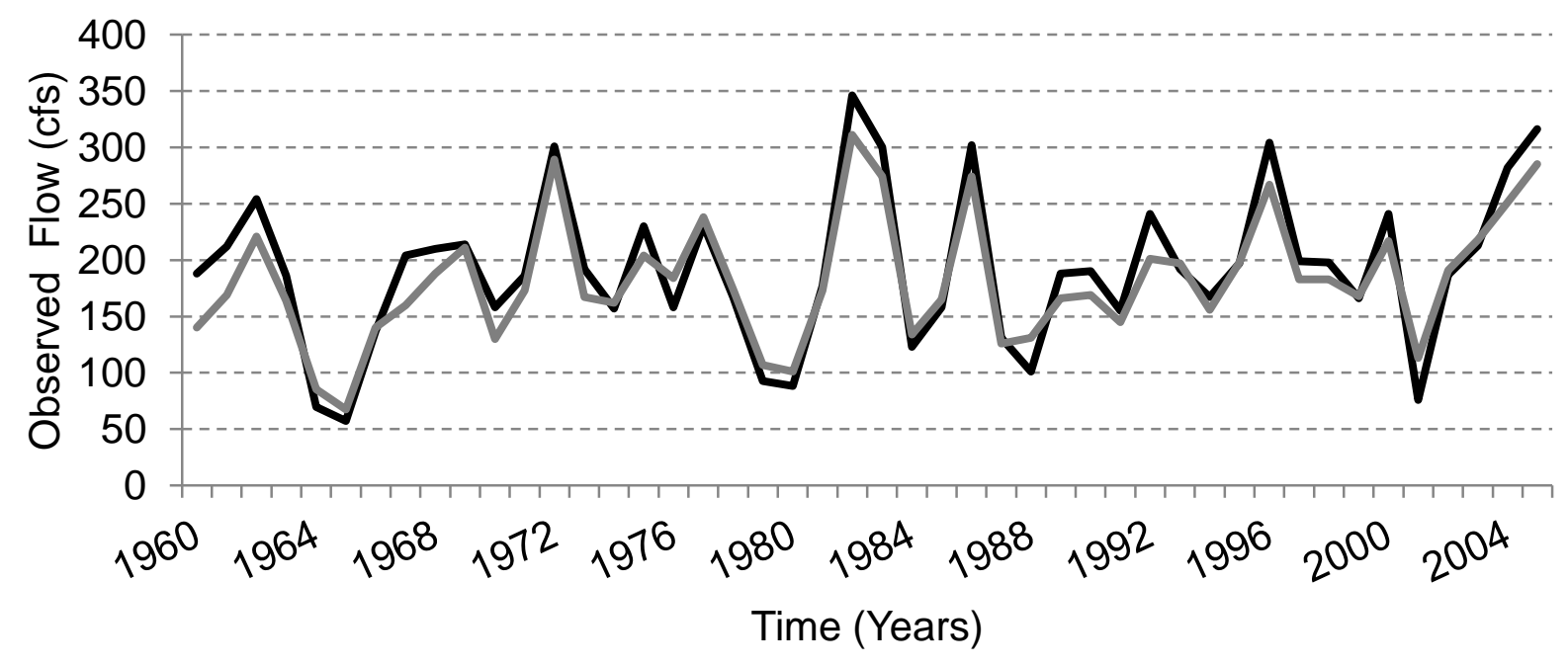

-Observed Data $\quad$ Simulated Data

(b) Time (Years) Vs Flow Data

Figure 5. Annual Calibration Results $(1 \mathrm{cfs}=0.0283168 \mathrm{cms})$ 


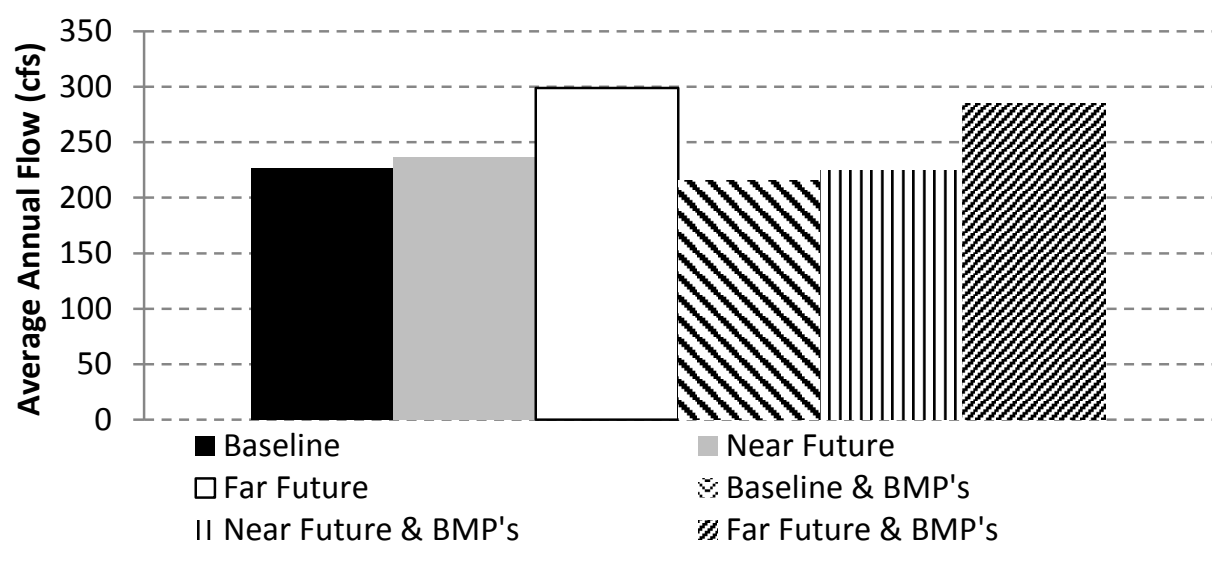

(a)
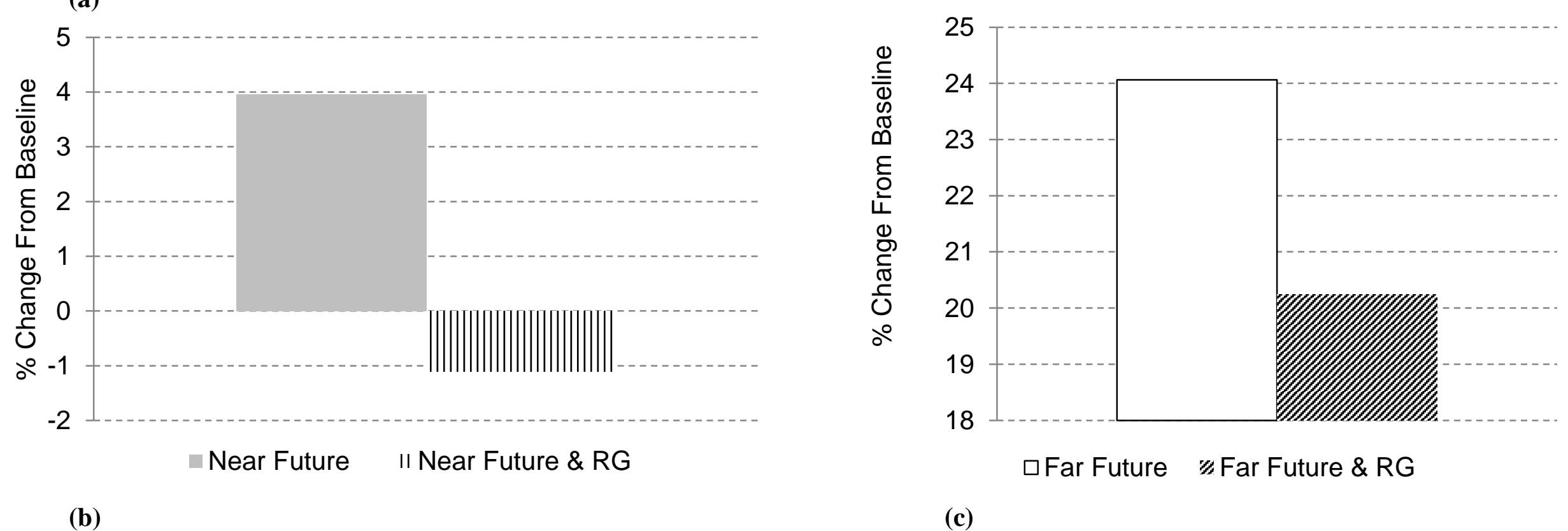

(b)

(c)

Figure 6 Comparison of all senarios as average flow and \% change from basline on yearly time step. (a) Avarage Annual Flow Vs. All Scenarios (b) \% Change From Baseline Vs. Near Future Senarios (c) \% of Change From Baseline Vs. Far Future Senarios $(1 \mathrm{cfs}=\mathbf{0 . 0 2 8 3 1 6 8} \mathrm{cms})$ 


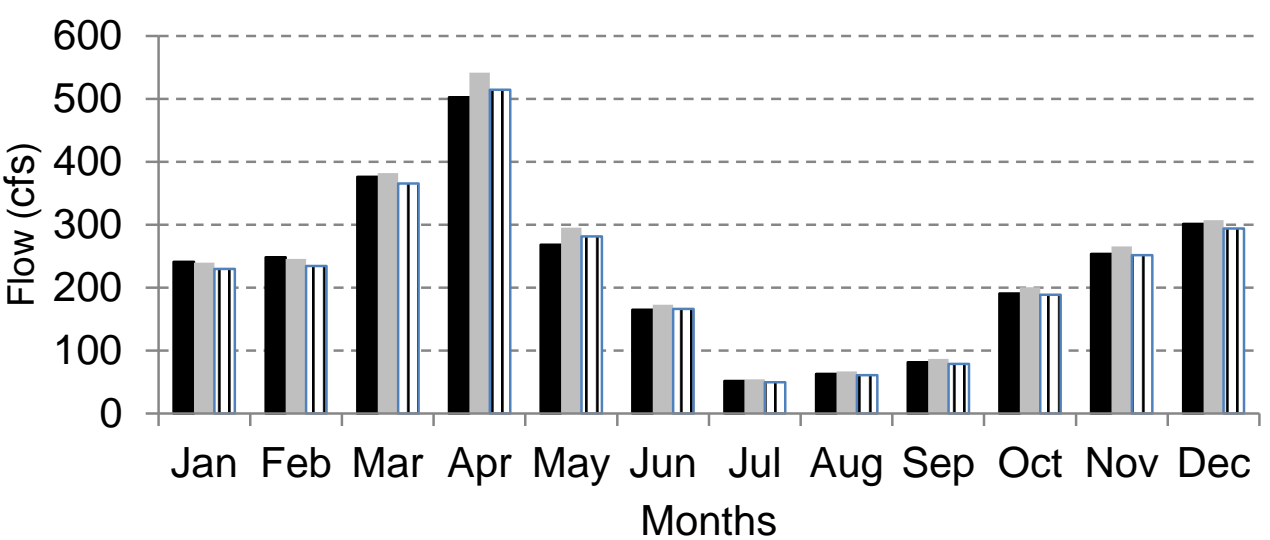

-Baseline $\quad$ Near Future $\quad$ Near Future \& BMP's

(a)

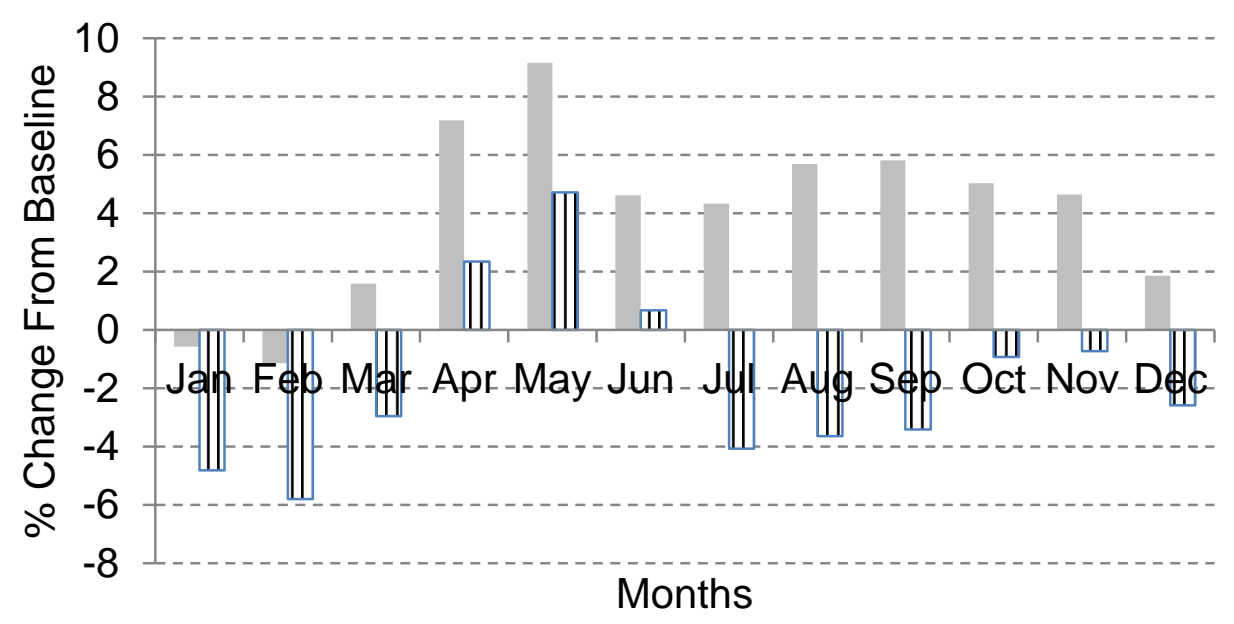

Near Future $\quad$ Near Future \& BMP's

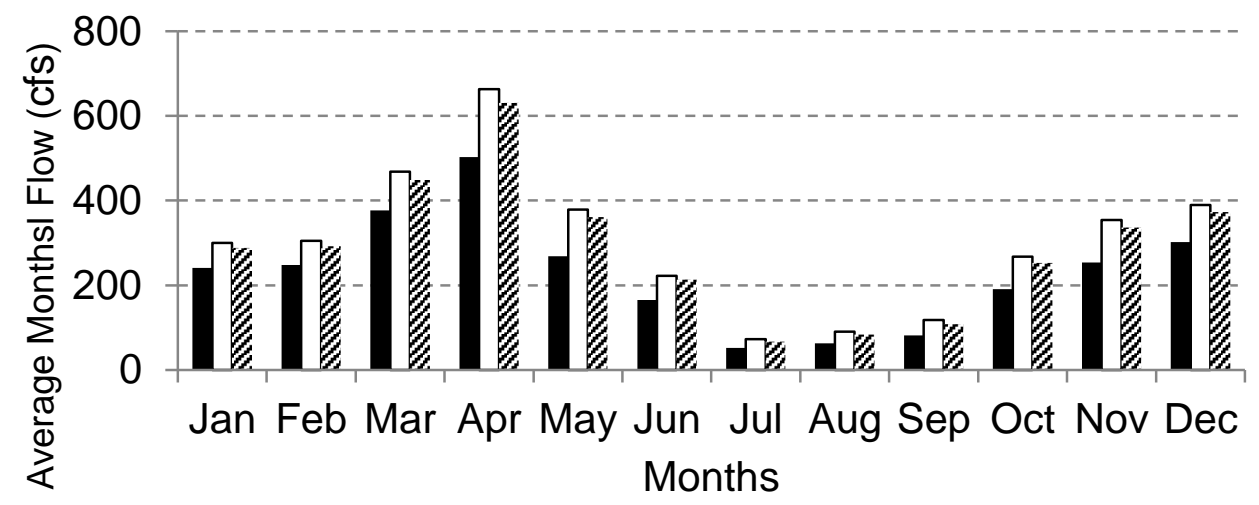

- Baseline $\square$ Far Future \#Far Future \& BMP's

(b)

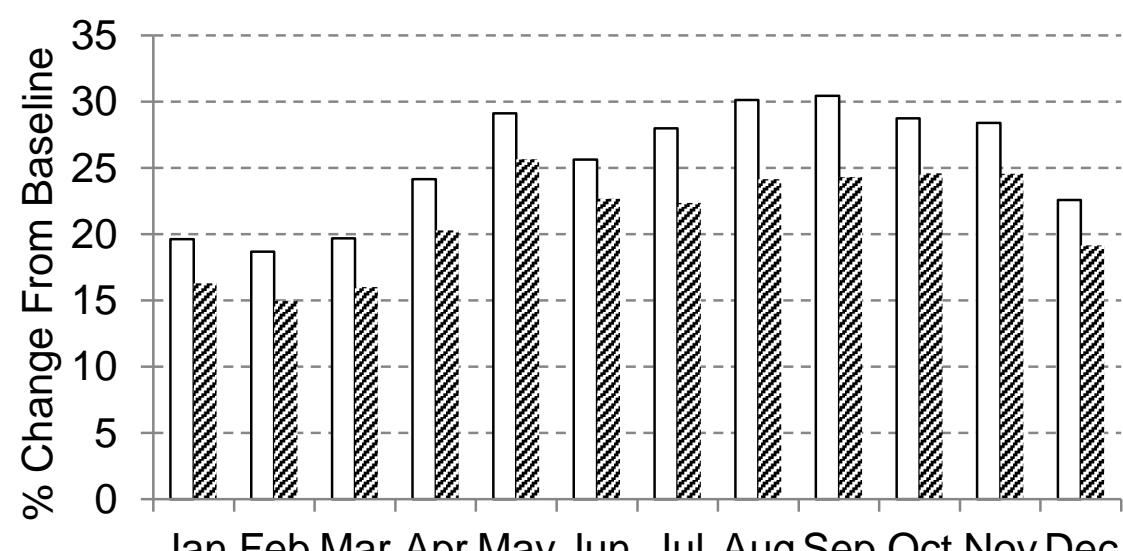

Jan Feb Mar Apr May Jun Jul Aug Sep Oct Nov Dec

Months

$\square$ Far Future \#Far Future \& BMP's

(d)

(c)

Figure 7. Seasonal impacts of climate change (a) Average Monthly Flows (cfs) Vs. Near Future Scenarios (b) Average Monthly Flow (cfs ) Vs. Far Future Scenarios (c) \% Change From Baseline Vs. Near Future Scenarios (d) \% Change From Baseline Vs. Far Future Scenarios 


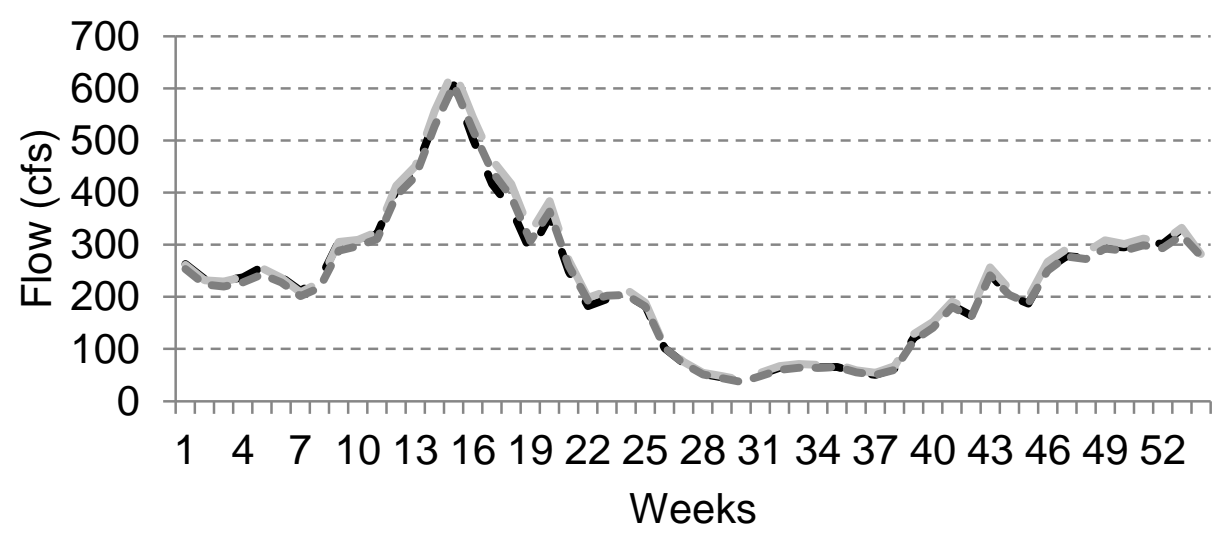

- - Baseline —- Near Future - - - Near Future \& BMP's

(a)

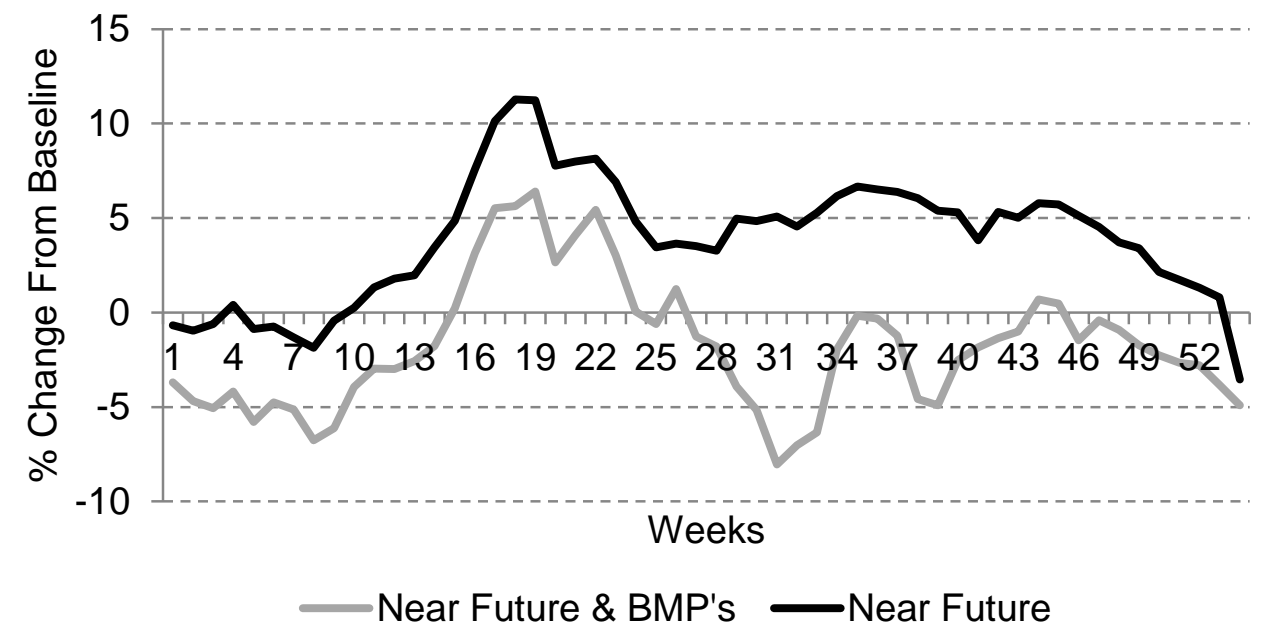

(c)

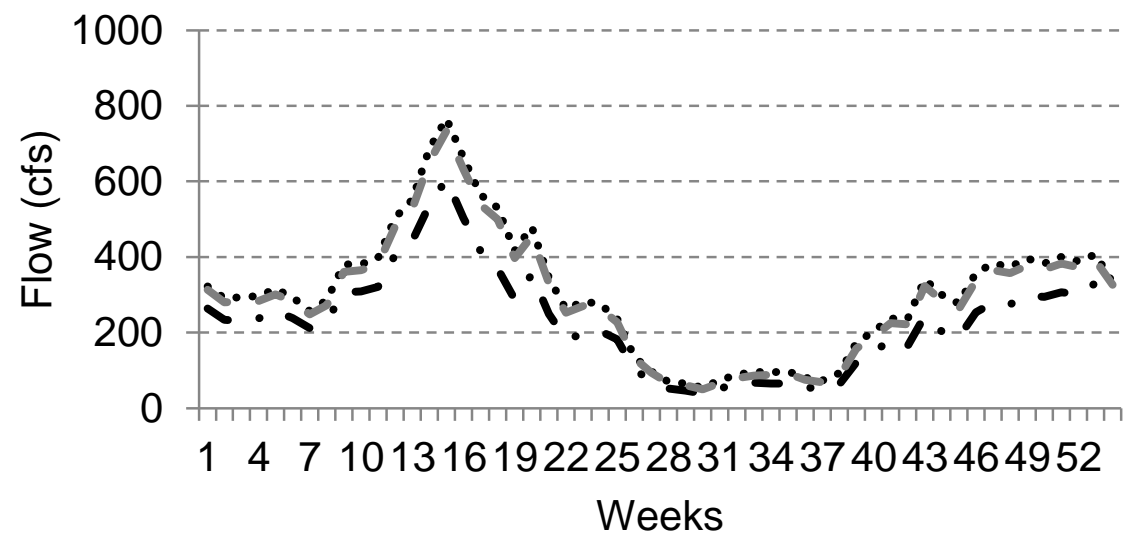

- - Baseline ...... Far Future - - Far Future \& BMP's

(b)

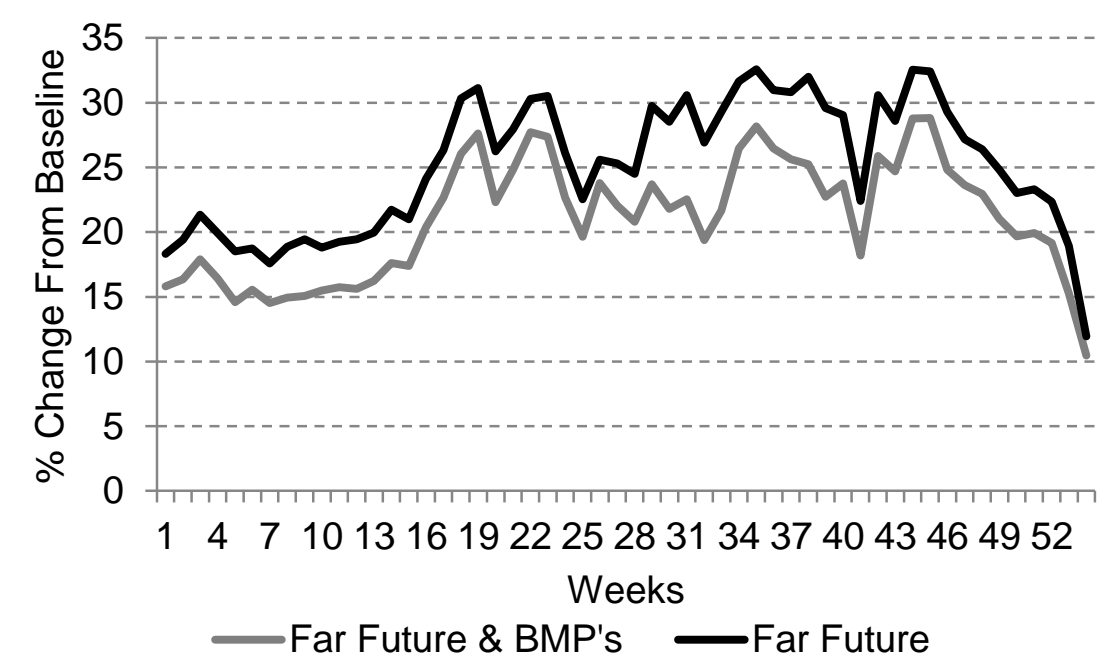

(d)

Figure 8. Seasonal Impacts of Climate Change (a) Flows (cfs) Vs. Near Future Weeks b) Flow (cfs ) Vs. Far Future Weeks (c) $\%$ Change from Baseline Vs. Near Future Weeks (d) \% Change from Baseline Vs. Far Future Scenarios $(1 \mathrm{cfs}=0.0283168 \mathrm{cms})$ 


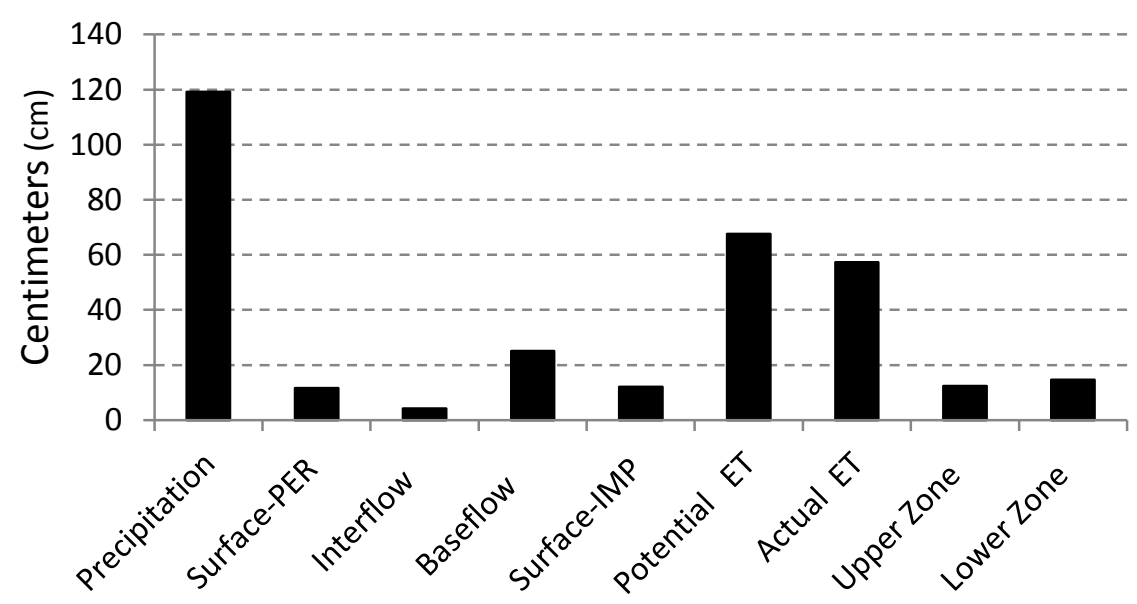

(a)

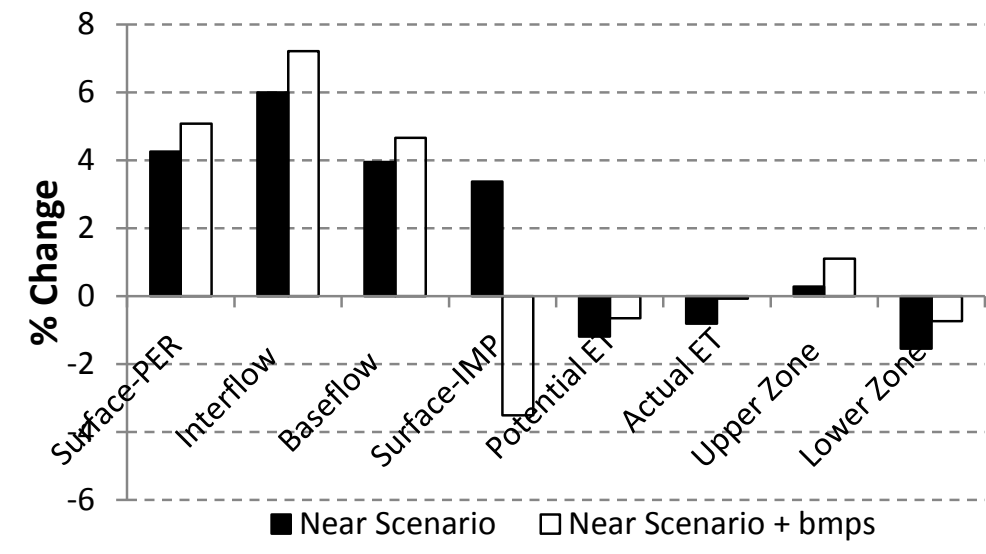

(b)

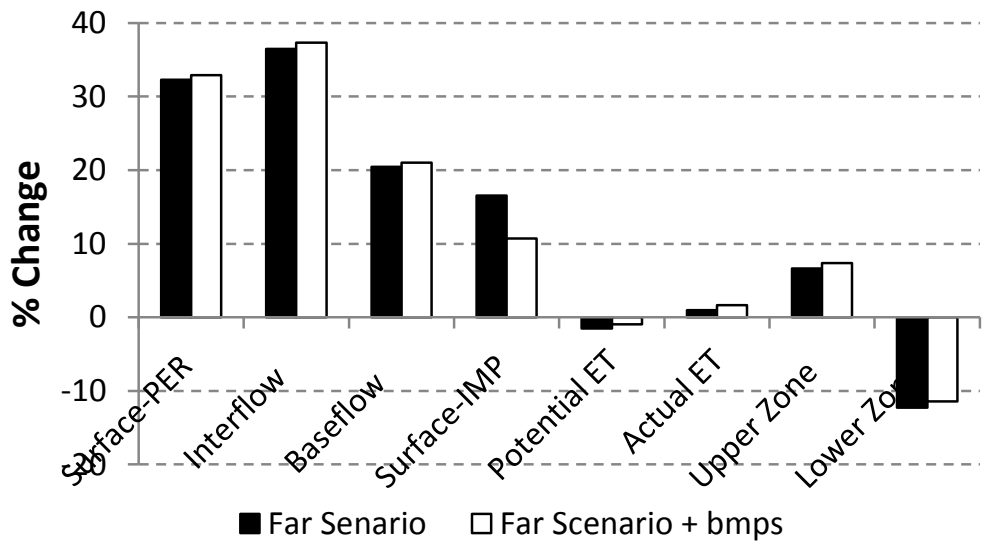

(c)

Figure 9. Impact on watershed processes as \% change for each scenario (a) Baseline Model (b) \% Change from Baseline Vs. Near Future scenario (c) \% Change from Baseline Vs. Far Future scenario 